KILAT

Vol. 10, No. 1, April 2021, P-ISSN 2089-1245, E-ISSN 2655-4925

DOI: https://doi.org/10.33322/kilat.v10i1.612

\title{
Penggunaan 3D Landmark Untuk Pengenalan Masjid Di Kota Bekasi Menggunakan Metode Prototype
}

\author{
Ndaru Ruseno ${ }^{1}$; Satria $^{2}$ \\ ${ }^{1}$ Program Studi/Jurusan Tehnik Informatika, STMIK Bani Saleh \\ ${ }^{2}$ Program Studi/Jurusan Sistem Informasi, STMIK Bani Saleh \\ ${ }^{1}$ ndarumantap@gmail.com \\ ${ }^{2}$ satria1905@gmail.com
}

\begin{abstract}
The mosque is the center of Muslim activities. The development of the mosque at this time so fast it can be seen from the City to remote villages. Bekasi City has 12 districts and in each district there are already many mosques that are easy to find. Each mosque must have a different architecture. The difference of each mosque building architecture is what makes Muslims want to visit the mosques to find out the beauty contained in the mosque's architecture. many of them first do a search on the search engine to find the mosque you want to visit Results Unfortunately on the search results there are still many who are drawn in $2 D$ in the form of photographs of the mosque. $2 D$ depiction is considered less effective because it can only see from one angle. Visualization is engineering in making drawings, diagrams, or animations to display information. Visualization usually depicts objects in 3D. With visualization, mosque objects can be shown as a whole. The research conducted is the prototyping method, where this method is used starting in the initial stages of design until the application is ready for use. Through the output of the mosque mosque visualization application in the District of Bekasi City, the author wants to show the overall shape of the mosque, mosque data, and the location of the mosque to make it easier for users before choosing a mosque to visit through a mobile-based application. This application includes mosques from 12 Subdistricts in the City of Bekasi, where in one district is represented by one mosque. The making of this application uses the PHP programming language.
\end{abstract}

Keywords: mosque, Bekasi City, 3D, Visualisation, Prototyping

\section{ABSTRAK}

Masjid adalah tempat kegiatan kaum muslimin. Masjid tersebar begitu pesat tersebar dari kota sampai ke desa. Kota Bekasi memiliki 12 kecamatan dan Pada setiap kecamatan sudah banyak berdiri masjidmasjid yang mudah untuk kita jumpai. Pada setiap masjid pasti memiliki arsitektur bangunan yang berbeda - beda. Perbedaan dari setiap arsitektur bangunan masjid inilah yang membuat kaum muslimin ingin mengunjungi masjid-masjid tersebut untuk mengetahui keindahan yang terdapat dari arsitektur masjid tersebut. banyak dari mereka terlebih dahulu melakukan pencarian di search engine untuk menemukan masjid yang ingin dikunjungi Hasil Sayangnya pada hasil pencarian masih banyak yang digambarkan secara 2D berupa hasil foto-foto masjid. Penggambaran 2D dianggap kurang efektif karena hanya bisa melihat dari satu sudut saja. Visualisasi merupakan rekayasa dalam pembuatan gambar, diagram, atau animasi untuk menampilkan suatu informasi. Visualisasi biasanya mengambarkan objek secara 3D. Dengan visualisasi, objek masjid dapat diperlihatkan keseluruhan. Penelitian yang dilakukan adalah dengan metode prototyping, dimana metode ini digunakan mulai dalam tahap awal perancangan hingga aplikasi siap untuk digunakan. Lewat keluaran aplikasi visualisasi masjid landmark Kecamatan Kota Bekasi, penulis ingin memperlihatkan bentuk masjid secara keseluruhan, data masjid, dan lokasi masjid untuk mempermudah pengguna sebelum memilih masjid untuk dikunjungi melalui aplikasi berbasis mobile. Aplikasi ini memuat masjid dari 12 Kecamatan di Kota Bekasi, dimana pada satu kecamatan diwakili oleh satu masjid. Pembuatan aplikasi ini menggunakan bahasa pemprograman PHP

Kata kunci : Masjid, Kota Bekasi, 3 Dimensi, Visualisasi, Prototyping. 


\section{PENDAHULUAN}

Masjid adalah tempat kegiatan kaum muslimin. Disana seharusnya kaum muslimin memperbaiki masa depannya, baik dari segi din (agama), ekonomi, politik, sosial dan seluruh sendi kehidupan, sebagaimana para pendahulunya memfungsikan masjid secara maksimal [1]. Perkembangan masjid pada masa sekarang ini yang begitu pesat itu dapat dilihat dari kota sampai ke pelosok desa. Masjid mudah kita jumpai dimana saja, baik di terminal, tempat rekreasi, dan di lembaga-lembaga pendidikan. Mereka membuat masjid di berbagai tempat dengan harapan agar mempermudah proses ibadah yang akan mereka kerjakan. Hal itu boleh-boleh saja dilakukan mengingat sekarang ini banyak orang yang memiliki mobilitas tinggi, hingga mereka dituntut untuk berpacu dengan waktu. Kehadiran masjid-masjid di sekitar mereka sedikit banyak akan membantu karena tidak perlu waktu lama untuk mendatangi masjid dan shalat berjamaah di dalamnya.

Kota Bekasi merupakan sebuah kota yang terdiri dari 12 kecamatan [2].Pada setiap kecamatan di Kota Bekasi tentunya sudah banyak berdiri masjid-masjid yang mudah untuk kita jumpai Pada setiap masjid di setiap kecamatan yang ada di kota bekasi pasti memiliki arsitektur bangunan yang berbeda-beda. Sayangnya pada hasil pencarian masih banyak yang digambarkan secara 2D berupa hasil foto-foto masjid.

Berdasarkan penjelasan diatas penulis mencoba menyajikan keluaran sebuah aplikasi yang dapat membantu masyarakan luas khususnya umat muslim yang ingin berkunjung untuk melakukan ibadah atau bahkan berwisata ke semua kecamatan di Kota Bekasi melalui pemilihan salah satu masjid yang mewakili satu kecamatan di setiap kecamatan yang ada di Kota Bekasi.Perbedaan dengan beberapa penelitaan sebelumnya [3] [4] adalah pada point visualisasi bangunan arsitektur masjid secara 3D serta informasi tentang lokasi keberadaan masjid tersebut di dalam aplikasi berbasis mobile dan juga platform web. Aplikasi ini diharapkan dapat membantu pengguna agar dapat mengetahui dan mengenali bangunan masjid secara 3D yang dimiliki oleh berbagai kecamatan yang berlokasi di Kota Bekasi. Dari hal diatas maka penulis ingin membuat suatu program aplikasi dengan judul aplikasi visualisasi masjid landmark setiap kecamatan di kota bekasi menggunakan 3D.

\section{METODE PENELITIAN}

\subsection{Visualisasi}

Definisi viusalisasi adalah menggunakan teknologi komputer sebagai pendukung untuk melakukan penggambaran data visual yang interaktif untuk memperkuat pengamatan [5] . terdapat dua konsep visualisasi, yaitu scientific visualisation dan information visualisation. Keduanya membuat model grafis dan menyajikan data secara visual yang berinteraksi langsung dengan pengguna untuk melakukan eksplorasi dan memperoleh informasi yang terdapat dalam data [6].

Berdasarkan definisi diatas dapat disimpulakan bahwa visualisasi adalah suatu teknik penggunaan komputer untuk menemukan metode terbaik dalam menampilkan data. Dengan menggunakan visualisasi, data yang ditampilkan dapat mempermudah peneliti untuk melihat data yang sulit dilihat dengan pemikiran sehingga peneliti bisa mengamati simulasi dan komputasi, juga memperkaya proses penemuan ilmiah dan mengembangkan pemahaman yang lebih dalam dan tak diduka, salah satu contohnya adalah dengan menampilkan data atau informasi dalam bentuk gambar, contoh : grafik, struktur tree, pola, warna. 


\section{KILAT}

Vol. 10, No. 1, April 2021, P-ISSN 2089-1245, E-ISSN 2655-4925

DOI: https://doi.org/10.33322/kilat.v10i1.612

\subsection{Konsep Tiga Dimensi}

3D atau 3 Dimensi adalah sebuah objek / ruang yang memiliki panjang, lebar dan tinggi yang memiliki bentuk. 3D tidak hanya digunakan dalam matematika dan fisika saja melainkan dibidang grafis, seni, animasi, komputer dan lain-lain. Konsep tiga dimensi atau 3D menunjukkan sebuah objek atau ruang memiliki tiga dimensi geometris yang terdiri dari: kedalaman, lebar dan tinggi di gambar 1. Contoh tiga dimensi suatu objek / benda adalah bola, piramida atau benda spasial seperti kotak sepatu seperti di gambar 2 .Istilah "3D" juga (dan salah) yang digunakan (terutama bahasa Inggris) untuk menunjukkan representasi dalam grafis komputer (digital), dengan cara menghilangkan gambar stereoscopic atau gambar lain dalam pemberian bantuan, dan bahkan efek stereo sederhana, yang secara konstruksi membuat efek 2D (dalam perhitungan proyeksi perspektif, shading).

Mengacu pada tiga dimensi spasial, bahwa 3D menunjukkan suatu titik koordinat Cartesian $\mathrm{X}$, Y dan Z [7]. Penggunaan istilah 3D ini dapat digunakan di berbagai bidang dan sering dikaitkan dengan hal-hal lain seperti spesifikasi kualitatif tambahan (misalnya: grafis tiga dimensi, 3D video, film 3D, kacamata 3D, suara 3D). Istilah ini biasanya digunakan untuk menunjukkan relevansi jangka waktu tiga dimensi suatu objek, dengan gerakan perspektif untuk menjelaskan sebuah "kedalaman" dari gambar, suara, atau pengalaman taktil. Ketidakjelasan istilah ini menentukan penggunaannya dalam beberapa kasus yang tidak jelas juga yaitu penggunaannya tidak hanya pada contoh-contoh diatas melainkan (sering dalam iklan dan media).
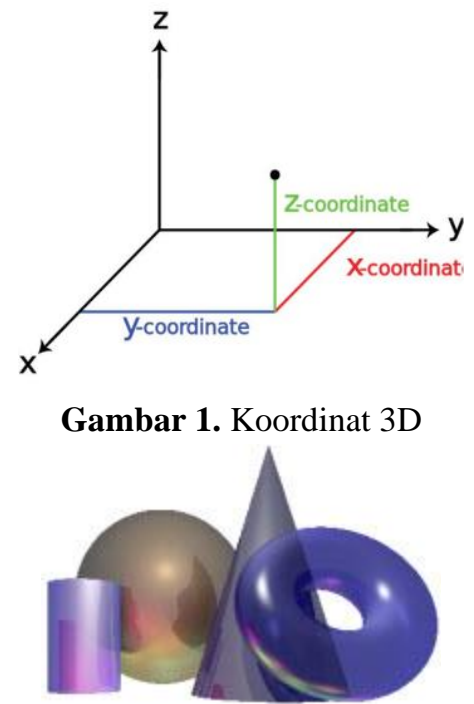

Gambar 1. Objek 3D

\subsection{Pemodelan Tiga Dimensi}

Pemodelan merupakan membentuk suatu benda - benda bisa juga sebuah obyek. Membuat dan mendesain obyek tersebut sehingga terlihat seperti hidup [6]. Sesuai dengan obyek dan basisnya, proses ini secara keseluruhan dikerjakan di komputer. Melalui konsep dan proses desain, keseluruhan obyek bisa diperlihatkan secara 3 dimensi, sehingga banyak yang menyebut hasil ini sebagai pemodelan 3 dimensi (3D modelling). Pada beberapa aspek yang harus dipertimbangkan bila membangun model obyek, kesemuanya memberi kontribusi pada kualitas hasil akhir. Hal-hal tersebut meliputi metoda untuk mendapatkan atau membuat data yang mendeskripsikan obyek, tujuan dari model, tingkat kerumitan, perhitungan biaya, kesesuaian dan kenyamanan, serta kemudahan manipulasi model. 
Selanjutnya Proses pemodelan Tiga Dimensi ini membutuhkan perancangan yang dibagi dengan beberapa tahapan untuk pembentukan. Seperti obyek apa yang ingin dibentuk sebagai obyek dasar, metoda pemodelan obyek 3D, pencahayaan dan animasi gerakan obyek sesuai dengan urutan proses yang akan dilakukan selanjtunya . Pada gambar dibawah memperlihatkan proses pemodelan pada 3D.

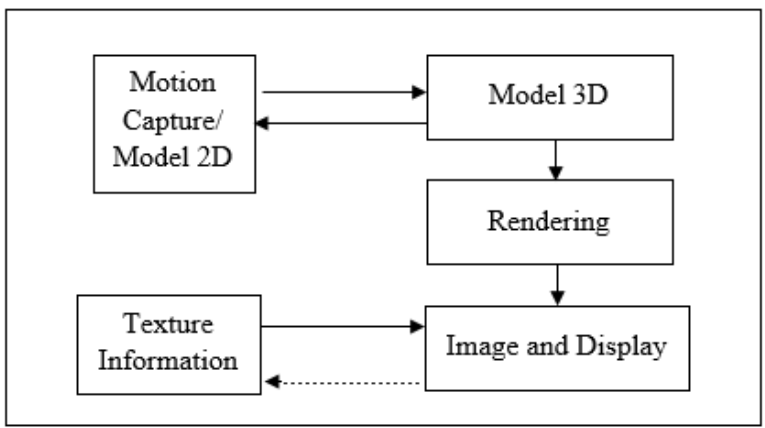

Gambar 3. Proses Pemodelan 3D

Pada gambar 3 terlihat bahwa 5 bagian yang saling terhubung dan mendukung untuk terciptanya sebuah model 3D. Pada tujuan dan fungsi dari masing - masing bagian tersebut adalah proses yang akan dijelaskan dibawah ini yaitu:

a. Motion Capture / Model 2D

yaitu sebuah langkah awal untuk menentukan bentuk model obyek yang akan dibangun dalam bentuk 3D. Penekanannya adalah pada obyek berupa gambar wajah yang sudah dibentuk intensitas warna tiap pixelnya dengan metode Image Adjustment Brightness/Contrast, Image Color Balance, dan tampilan Convert Mode RGB dan dalam format JPEG. Dalam tahap ini digunakan aplikasi grafis seperti Adobe Photoshop atau lainya yang sejenis.

Proses penentuan ini obyek 2D memiliki pengertian bahwa obyek 2D yang akan dibentuk merupakan dasar pemodelan 3D. Keseluruhan obyek 2D dapat dimasukkan dengan jumlah lebih dari satu, model yang akan dibentuk sesuai dalam kebutuhannya. Selanjutnya step rekayasa hasil obyek 2D dapat dilanjutkan dengan aplikasi program grafis seperti Photoshop dan lain aplikasi lain sejenis, pada tahap pemodelan 3D, pemodelan yang dimaksud dilakukan masih manual. Dalam basis obyek 2D yang sudah ditentukan sebagai acuan. Pemodelan obyek 3D memiliki corak yang berbeda dalam pengolahannya, corak tersebut penekanannya terletak pada seubah bentuk permukaan obyek.

b. Metode Modeling 3D

Beberapa cara dan metode yang digunakan untuk pemodelan 3D. Bentuk jenis metode pemodelan obyek yang disesuaikan dengan kebutuhannya seperti dengan nurbs dan polygon ataupun subdivision. Modeling polygon adalah bentuk segitiga dan segiempat yang menentukan area dari permukaan sebuah karakter. Setiap bagian polygon menentukan sebuah bidang datar dengan meletakkan sebuah jajaran polygon sehingga kita bisa menciptakan bentuk-bentuk permukaan. Untuk mendapatkan permukaan yang halus, dibutuhkan banyak bidang polygon. Bila hanya menggunakan sedikit polygon maka object yang didapat akan terbagi sejumlah pecahan polygon Sedangkan Modeling dengan NURBS (Non Uniform Rational Bezier Spline) merupakan metode paling populer untuk membangun sebuah model yang organik. Kurva pada Nurbs dapat dibentuk dengan hanya tiga titik bagian saja. 


\section{KILAT}

Vol. 10, No. 1, April 2021, P-ISSN 2089-1245, E-ISSN 2655-4925

DOI: https://doi.org/10.33322/kilat.v10i1.612

Dibandingkan dengan kurva polygon yang membutuhkan banyak titik (verteks) metode ini lebih memudahkan untuk dikontrol. Satu titik CV (Control verteks) dapat mengendalikan satu area untuk proses tekstur.

c. Rendering

Pada proses akhir dari keseluruhan proses pemodelan ataupun animasi komputer. Dalam rendering, semua data-data yang sudah dimasukkan dalam proses modeling, animasi, texturing, pencahayaan dengan parameter tertentu akan diterjemahkan dalam sebuah bentuk output.

\section{d. Texturing}

Selanjutnya Proses texturing ini untuk menentukan karakterisik sebuah materi obyek dari segi tekstur. Untuk materi sebuah objek bisa digunakan aplikasi properti tertentu seperti reflectivity, transparency, dan refraction. Texture kemudian bisa digunakan untuk mengcreate berbagai variasi warna pattern, tingkat kehalusan/kekasaran sebuah lapisan objek secara lebih detail.

e. Image dan Display

Bagian ini merupakan hasil akhir dari keseluruhan proses dari pemodelan. umumnya obyek pemodelan yang menjadi output adalah berupa gambar untuk kebutuhan koreksi pewarnaan, pencahayaan, atau visual effect yang dimasukkan pada tahap teksturing pemodelannya [8].

\section{ANALISA DATA}

Metode pemecahan masalah yang digunakan dalam pembuatan aplikasi ini adalah metode prototyping. Metode prototyping adalah sebuah proses yang bertujuan membangun sistem berdasarkan kebutuhan user yang tidak mengidentifikasikan secara sangat jelas pada detail input, proses ataupun output.

Metode prototyping diawali dengan pengumpulan data kebutuhan. Pengumpulan data kebutuhan dilakukan dengan cara komunikasi, yang dapat berupa kuisioner atau wawancara dengan pengguna aplikasi. Pengembang dan pengguna aplikasi menentukan kebutuhan, tujuan dan gambaran suatu sistem. Pengembang kemudian membangun model prototype yang dapat menggambarkan sistem.

a. Tahap Pengumpulan Kebutuhan

Pada tahap pengumpulan kebutuhan, kebutuhan bahan dan data meliputi perancangan, pembangunan aplikasi, penerapan teknologi 3D dan sebagainya yang diperlukan dalam membangun aplikasi. Bahan dan data yang diperlukan bersumber pada observasi dan wawancara yang dilakukan langsung kepada DKM dari masing - masing masjid, serta studi literatur yang bersumber pada jurnal, artikel, situs internet, dan lain - lain.

Wawancara yang dilakukan bertujuan untuk mengetahui informasi dasar atau umum mengenai masjid, serta pengambilan foto masjid yang bertujuan sebagai aspek yang diperlukan dalam mendesain suatu bangunan atau tata letak bangunan masjid secara 3D.

b. Tahap Membangun Prototype

Pada tahap membangun prototype dilakukan pembuatan prototype objek masjid secara 3D. Pembuatan prototype ini berdasarkan dari foto - foto masjid yang telah diambil dari berbagai sudut pandang. Foto - foto tersebut dibuat menjadi objek-objek 3D masjid yang akan digunakan dalam aplikasi. 


\section{c. Tahap Evaluasi Prototype}

Pada tahap ini, penulis melakukan evaluasi apakah rancangan objek masjid 3D yang telah dibuat yang telah memenuhi kebutuhan atau belumnya, dan apakah ada yang harus ditambahkan atau tidaknya, jika telah sesuai dengan kebutuhan maka tahap selanjutnya lalu diambil.

d. Tahap Pengkodean Sistem

Pada tahap mengkodekan sistem, prototype yang sudah di sepakati diterjemahkan ke dalam bahasa pemrograman yang sesuai. Karena aplikasi yang ditampilkan berbentuk website dan android, maka bahasa pemprograman yang dipakai pada website adalah PHP. Untuk bisa ditampilkan di program PHP, hasil prototype yang dibuat didalam software 3D yang masih menggunakan format file 3D seperti .3ds, .fbx, .obj, dan lain - lain harus di convert kedalam format file yang didukung oleh PHP karena PHP tidak mendukung jenis format file 3D. Dan untuk bisa di tampilkan di android harus dijadikan sebuah aplikasi android.

\section{e. Tahap Pengujian Sistem}

Setelah sistem sudah menjadi suatu perangkat lunak yang siap pakai, harus dites dahulu sebelum digunakan. Pengujian ini dilakukan dengan Black Box.

\section{f. Tahap Evaluasi Sistem}

Setelah itu pengguna mengevaluasi apakah sistem yang sudah jadi sudah sesuai dengan yang diharapkan. Jika ya, maka aplikasi siap digunakan secara umum. Jika tidak, ulangi langkah mengkodekan dan menguji sistem.

g. Tahap Menggunakan Sistem

Pada tahap ini, aplikasi telah tersebar secara luas dan dapat digunakan.

\section{HASIL DAN PEMBAHASAN}

Setelah dilakukan analisa serta perancangan, Selanjutnya melanjutkan dengan mewujudkan hasil yang nantinya akan digunakan untuk menguji pada kesesuaian visualisasi masjid landmark kecamatan kota bekasi menggunakan 3D yang dibuat dengan sistem yang telah dirancang pada bab sebelumnya. Agar visualisasi masjid landmark kecamatan kota bekasi menggunakan 3D yang dibuat dapat diimplementasikan, maka diperlukan komponen pendukung baik berupa perangkat keras maupun perangkat lunak.

\section{A. Perangkat Keras}

Adapun perangkat keras yang digunakan dalam penelitian ini adalah :

a. Laptop Lenovo E40-80 GID

1) Layar TFT LCD dengan LED backlight 14 inci resolusi $1366 \times 768$ piksel Anti-Glare Display

2) Prosesor Intel Core i3-5010U dual-core $2,1 \mathrm{GHz}$

3) Grafis AMD Radeon R5 M330 VRAM 2GB

4) Memori RAM 2GB DDR3L upgradeable to 8GB DDR3L

5) Storage hard disk 500GB

6) Konektifitas LAN, WiFi, Bluetooth, Port USB 3.0, Port HDMI, fingerprint sensor, DVDRW, Dolby Advanced Audio

7) Baterai 4 cell $32 \mathrm{Wh}$ dengan daya tahan hingga 6 jam

8) Sistem Operasi Windows 8.1 SL 


\section{KILAT}

Vol. 10, No. 1, April 2021, P-ISSN 2089-1245, E-ISSN 2655-4925

DOI: https://doi.org/10.33322/kilat.v10i1.612

B. Bahasa Pemprograman

Bahasa pemprograman yang digunakan adalah PHP, JavaScribt, dan HTML merupakan bahasa pemprograman di Macromedia Dreamweaver8. PHP berguna sebagai pemanggil halaman lain, JavaScribt sebagai pembuat efek pada botton masjid, HTML sebagai tampilan website.

Pada tahap ini penulis akan mempresentasikan aplikasi 3 Dimension Mosque. Adapun yang akan dipresentasikan adalah sebagai berikut :

\subsection{Halaman Utama}

Pada halaman utama pada gambar 4, terdiri dari tampilan 3D map kota Bekasi yang bisa diputar 360 derajat, button masjid, list nama masjid, dan pada footernya terdapat button start, button profile, dan button mosque.

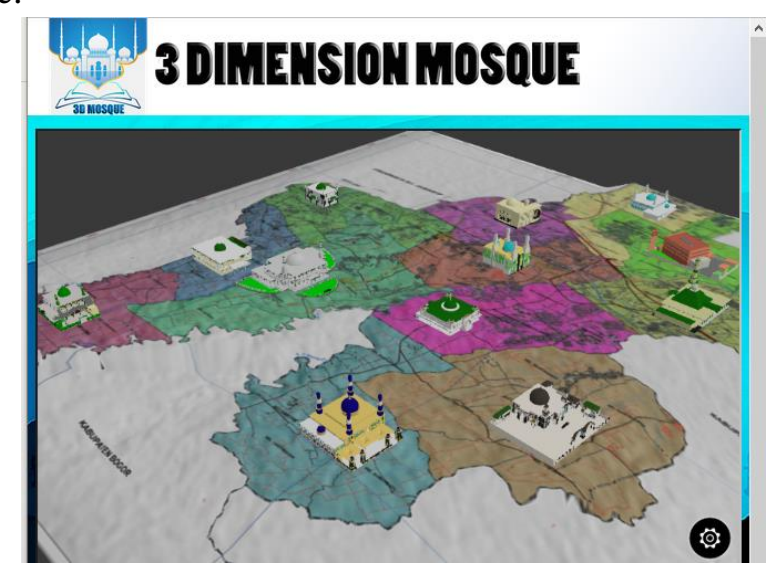

Gambar Error! No text of specified style in document.. Tampilan Halaman Utama

\subsection{Halaman Objek 3D dan Data Masjid}

Pada halaman objek 3D dan data masjid, terdiri dari tampilan objek 3D masjid yang dapat diputar 360 derajat, data masjid yang dimana pada alamat masjid langsung terhubung ke google map, galeri untuk melihat gambar 2D masjid dan pada footernya terdapat button start, button profile, dan button mosque.

\subsubsection{Masjid Raya Arridlwan - Medansatria}

Untuk masjid Raya Arridlwan pada gambar 5, pembuatan visualisasi bisa dilihat sampai tampak dalam bangunan dikarenakan bangunan masjid yang terbuka.

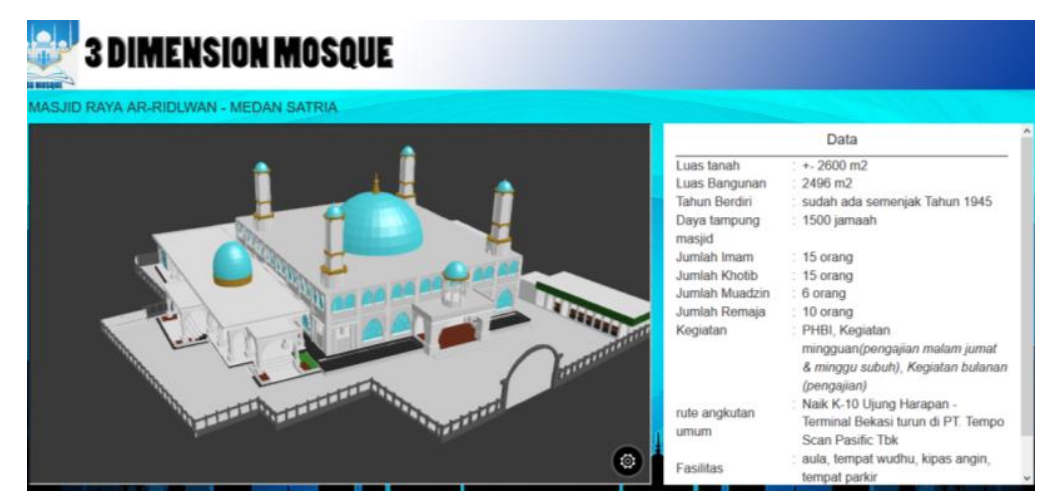

Gambar 5. Masjid Raya Arridlwan - Medansatria 


\subsubsection{Masjid Raya Al - Azhar Summarecon Bekasi - Bekasi Utara}

Untuk masjid Al - Azhar Summarecon Bekasi - Bekasi Utara pada gambar 6, pembuatan visualisasi bisa dilihat sampai tampak dalam bangunan dikarenakan bangunan masjid yang terbuka.

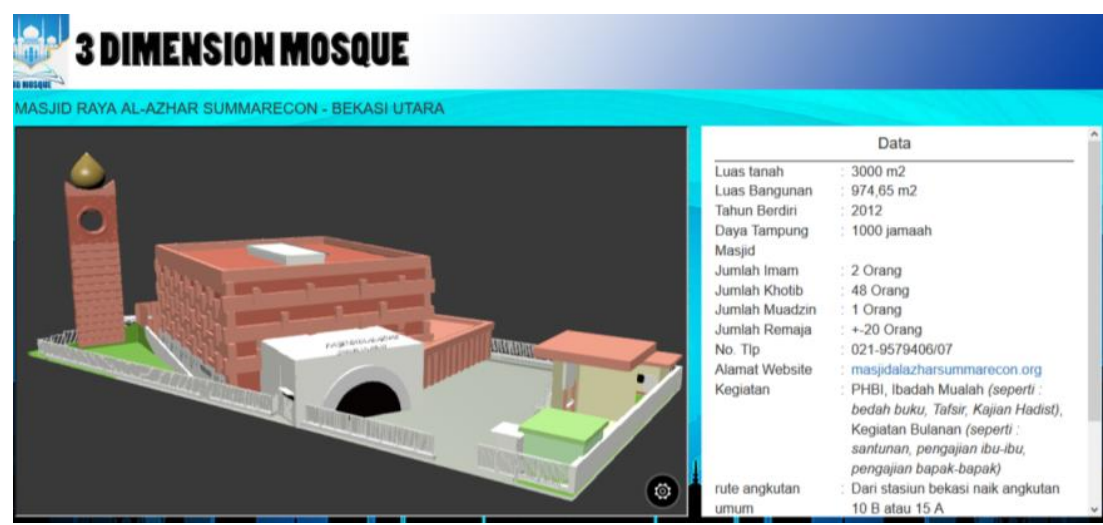

Gambar 6. Masjid Raya Al - Azhar Summarecon Bekasi - Bekasi Utara

\subsection{Hasil Pengujian}

Berdasarkan rencana pengujian aplikasi yang disusun, maka dapat dilakukan beberapa tahap pengujian seperti berikut :

\subsubsection{Pengujian Menampilkan 3D pada pengujian laptop}

Tabel 1. Pengujian Laptop

\begin{tabular}{|c|c|}
\hline Laptop & hasil \\
\hline Lenovo E40-80 GID & $\begin{array}{c}\text { Mampu menampilkan tampilan website dengan jelas dan } \\
\text { objek 3D dapat diputar 360 derajat }\end{array}$ \\
\hline Lenovo L420 & $\begin{array}{c}\text { Mampu menampilkan tampilan website dengan jelas dan } \\
\text { objek 3D dapat diputar 360 derajat }\end{array}$ \\
\hline Lenovo G4--35 & $\begin{array}{c}\text { Mampu menampilkan tampilan website dengan jelas dan } \\
\text { objek 3D dapat diputar 360 derajat }\end{array}$ \\
\hline
\end{tabular}

\subsubsection{Pengujian Smartphone}

Tabel 2. Pengujian Smartphone

\begin{tabular}{|l|l|}
\hline Smartphone & hasil \\
\hline Xiaomi redmi note 3 pro & $\begin{array}{c}\text { Mampu menampilkan tampilan website dengan jelas dan } \\
\text { objek 3D dapat diputar 360 derajat }\end{array}$ \\
\hline Xiami redmi note 4 & $\begin{array}{c}\text { Mampu menampilkan tampilan website dengan jelas dan } \\
\text { objek 3D dapat diputar 360 derajat }\end{array}$ \\
\hline Xiami mi 4C & $\begin{array}{c}\text { Mampu menampilkan tampilan website dengan jelas dan } \\
\text { objek 3D dapat diputar 360 derajat }\end{array}$ \\
\hline
\end{tabular}

\subsubsection{Hasil Perbandingan Pengujian Pengaruh Aplikasi}

Berdasarkan hasil kuesioner pengaruh sebelum dan sesudah menggunakan aplikasi dari skala 1 sampai 5, maka dapat ditarik kesimpulan bahwa pengaruh yang didapatkan menjadi sangat baik dengan ketentuan meningkat sebesar $21.86 \%$ dari sebelumnya $65.87 \%$ menjadi $87.73 \%$ setelah menggunakan aplikasi 3 Dimension Mosque. Seperti yang terlihat pada tabel 4. 


\section{KILAT}

Vol. 10, No. 1, April 2021, P-ISSN 2089-1245, E-ISSN 2655-4925

DOI: https://doi.org/10.33322/kilat.v10i1.612

Tabel 3. Hasil Perbandingan Pengujian Pengaruh Aplikasi

\begin{tabular}{|c|c|c|c|}
\hline No. & Kuesioner & Nilai & Persentase \\
\hline 1 & Sebelum menggunakan aplikasi & 247 & $65.87 \%$ \\
\hline 2 & Sesudah menggunakan aplikasi & 329 & $87.73 \%$ \\
\hline \multicolumn{2}{|c|}{ Jumlah selisih perbandingan } & 82 & $21.86 \%$ \\
\hline
\end{tabular}

\section{KESIMPULAN DAN SARAN}

\subsection{Kesimpulan}

Berdasarkan hasil penelitian yang dilakukan penulis, maka dapat disimpulkan sebagai berikut:

1. Aplikasi 3 Dimension Mosque berhasil memperlihatkan visualisasi bangunan masjid secara 3D yang dibuat menggunakan software Blender untuk objek 3D.

2. Aplikasi 3 Dimension Mosque berhasil menampilkan 12 masjid dalam satu aplikasi, dimana pada setiap kecamatan diwakili satu masjid. Arsitektur dan data masjid dapat dilihat dengan baik melalui website dan aplikasi android.

3. Dari hasil perhitungan kuisioner dengan melibatkan 15 responden, Aplikasi 3 Dimension Mosque berhasil memperlihatkan visualisasi bangunan masjid secara 3D dengan tingkat kemiripan mencapai $84.95 \%$.

\subsection{SARAN}

Berdasarkan hasil penelitian yang dilakukan penulis, adapun beberapa hal yang perlu penulis sarankan yaitu :

a. Menambahkan teksture pada objek masjid 3D sehingga tingkat kemiripannya menjadi semakin dekat dengan Objek sebenarnya.

b. Merubah tampilan Aplikasi menjadi lebih responsive ketika ditampilkan pada aplikasi android.

c. Memperkecil ukuran file 3D sehingga mudah pada saat menampilkannya.

d. Bisa menampilkan view 360 derajat seperti google street atau 360 derajat pada facebook.

\section{DAFTAR PUSTAKA}

[1] I. Bafadhol, "Lembaga Pendidikan Islam Di Indoesia,” J. Edukasi Islam. J. Pendidik. Islam, 2017.

[2] BPS Kota Bekasi, "Kota Bekasi dalam Angka 2018," BPS Kota Bekasi, 2018.

[3] Wahyudin, S. Wahyudi, and M. I. A. Robbi, "Visualisasi Masjid Agung Rangkasbitung Berbasis 3D Dengan Menggunakan Google Sketchup dan After Effect," J. Pengemb. Ris. dan Obs. Sist. Komput., 2015.

[4] R. Wirawan, "Visualisasi Bangunan pada Masjid Al-Markaz Islami Makassar berbasis Aplikasi 3 DImensi," J. IT STMIK Handayani, 2014.

[5] M. Lasiun, "KEBERKESANAN KAEDAH VISUALISASI: MENINGKATKAN KEUPAYAAN MENYELESAIKAN MASALAH MATEMATIK BERAYAT," Proc. ICECRS, 2016, doi: 10.21070/picecrs.v1i1.542.

[6] Frediarto Rudi Aditya, "Media Pembelajaran, Menggambar 3 dimensi," Pengemb. MEDIA PEMBELAJARAN MENGGAMBAR 3 Dimens. PADA STANDAR KOMPETENSI MENGGAMBAR DENGAN PERANGKAT LUNAK, 2014.

[7] E. Yanty Putri Nasution, "MENINGKATKAN KEMAMPUAN SPASIAL SISWA MELALUI PEMBELAJARAN GEOMETRI BERBANTUAN CABRI 3D," M A T H L I N E J. Mat. dan Pendidik. Mat., 2017, doi: 10.31943/mathline.v2i2.45. 
[8] “ANALISA KETELITIAN DAN KESESUAIAN PEMODELAN 3D DENGAN PENDEKATAN GEOMETRI DAN TEKNIK STRUCTURE FROM MOTION (SFM) PADA OBYEK BANGUNAN,” 2016, doi: 10.12962/j24423998.v12i1.2399. 